удК 336

\title{
ФІНАНСОВІ МОТИВИ ЗАСТОСУВАННЯ БЛОКЧЕЙН-ТЕХНОЛОГІЙ У БАНКІВСЬКІЙ СПРАВІ
}

\author{
FINANCIAL MOTIVES FOR THE APPLICATION \\ OF BLOCKCHAIN TECHNOLOGIES IN BANKING
}

\author{
Підхомний Олег Михайлович \\ доктор економічних наук, профресор, \\ Львівський національний університет імені Івана Франка \\ ORCID: https://orcid.org/0000-0003-2642-8657 \\ Демид Віктор Миколайович \\ студент, \\ Львівський національний університет імені Івана Франка \\ ORCID: https://orcid.org/0000-0002-2326-9665
}

Pidkhomnyi Oleg, Demyd Viktor

Ivan Franko National University of Lviv

\begin{abstract}
У статті розглянуто тенденції сучасного банківського ринку та визначено перспективи використання блокчейн-технологій у фрінансово-господарській діяльності банківських установ. Проаналізовано кроки України щодо формалізації та окреслення в правовому полі відносин, пов'язаних з віртуальними активами. Досліджено світовий досвід застосування блокчейн-технологій у банківській справі. Визначено поняття блокчейну та принципи функціонування цієї технології. Сфрормульовано головні переваги, недоліки та неоднозначні характеристики блокчейну з позиції безпеки банків. З'ясовано перешкоди, що стоять на заваді впровадження блокчейну у фінансове посередництво. Визначено основні фрінансові мотиви застосування блокчейну в банківській справі та з'ясовано характеристики, які узгоджуються або конфрліктують з окремими мотивами.
\end{abstract}

Ключові слова: банківська справа, блокчейн, віртуальні активи, трансакції, фрінансові мотиви.

В статье рассмотрены тенденции современного банковского рынка и определены перспективы использования блокчейн-технологий в фринансово-хозяйственной деятельности банковских учреждений. Осуществлен анализ шагов Украины по формализации и определению в правовом поле отношений, связанных с виртуальными активами. Исследован мировой опыт применения блокчейн-технологий в банковском деле. Определены понятия блокчейна и принципы работы этой технологии. Сорормулированы основные преимущества, недостатки и неоднозначные характеристики блокчейна с точки зрения безопасности банков. Выяснены препятствия, мешающие внедрению блокчейна в финансовое посредничество. Определены основные фринансовые мотивы применения блокчейна в банковском деле и выяснены характеристики, согласующиеся или конорликтующие с отдельными мотивам.

Ключевые слова: банковское дело, блокчейн, виртуальные активы, трансакции, финансовые мотивы.

The article considers the trends of the modern banking market and identifies prospects for the blockchain technologies use in the financial and economic activities of bank institutions. It was revealed that Ukraine is taking steps to formalize and delineate relations with virtual assets in the legal field. At the moment, the Ukrainian legislation related to the research topic is being clarified and finalized. Scientists have found that opinions on the use of blockchain technologies differ. According to some pessimistic forecasts, this technology will cause significant obstacles for bank institutions, but other scientists believe that blockchain technologies can help develop financial relations. The world experience of using blockchain technologies in banking has been studied. Currently, there is a growing number of businesses that are already involved in blockchain-related projects. It is also found that projects related to blockchain technologies in the banking sector are currently being developed and implemented. Among the implementers of such projects are: JP Morgan Chase, Bank of America, BNP Paribas and Fujitsu and JBA. The concept of blockchain as a distributed book technology and the principles of this technology are defined. The main advantages, disadvantages and ambiguous characteristics of the blockchain from the standpoint of bank security are formulated. The advantages of the blockchain include: reliability, compromise and security. The disadvantages of the studied technology include: energy dependence, energy consumption, new cyber vulnerabilities and the complexity of finan- 
cial monitoring. It was found that the ambiguous characteristics of blockchain technologies include: confidentiality, transparency, decentralization, lack of standards and novelty for customers. Obstacles to the implementation of the blockchain in financial intermediation have been identified. It is determined that the main financial motives for the use of blockchain in banking include the following: efficiency, security, autonomy and control. Characteristics that are consistent or conflicting with individual motives are identified.

Keywords: banking, blockchain, virtual assets, transactions, financial motives.

Постановка проблеми. В сучасних динамічних умовах розвитку економіки, широкого розповсюдження цифрових технологій, виходу фрінансового посередництва за межі фрінансових інститутів, набуває актуальності питання переваг і недоліків використання віртуальних активів та криптовалют, зокрема, й технологій на яких вони ґрунтуються.

Варто зауважити, що використання інноваційних технологій у банківській справі забезпечує досягнення довгострокового успіху, скорочення витрат, пов'язаних 3 посередництвом та прискорення здійснення трансакцій. Технологією, у якій низка дослідників вбачає такий потенціал $€-$ блокчейн. Актуальність дослідження цієї теми також пов'язана з тим, що блокчейн-технології здатні підвищити прозорість здійснення трансакцій, посприяти захисту даних та відходу від надмірної централізації срінансових посередників. $€$ підстави стверджувати, що Україна здійснює рух у напрямі врегулювання в правовому полі відносин, пов'язаних з обігом віртуальних активів.

Аналіз останніх досліджень і публікацій. Проблемам дослідження фрінансових мотивів використання блокчейн-технологій у банківській справі наразі присвячена незначна кількість наукових праць як вітчизняних вчених, так і іноземних науковців. Серед вчених, які здійснюють дослідження в цій темі варто відзначити: Dancho Petrov [3], Rebecca Lewis [4], Dulani Jayasuriya Daluwathumullagamage [5], Derrick Bonyuet [6], Manlu Liu [7], Marion Pauline Gauthier [8], Thomson Reuters [9], Najoua Elommal [12], Higginson M. [13].

Однак, незважаючи на різноплановість наукових поглядів щодо окресленої проблеми доречно зазначити, що в сучасних умовах розвитку цифрової економіки та постійних змін середовища функціонування фрінансових посередників виникає необхідність пошуку шляхів активізації їх інноваційної діяльності 3 метою забезпечення високого рівня конкурентоспроможності, прибутковості та довгострокового сталого розвитку.

Формування цілей статті. Метою статті $\epsilon$ визначення поняття блокчейн-технологій, їх головних характеристик та фрінансових мотивів застосування у банківській справі.
Виклад основного матеріалу дослідження. За останнє десятиліття банківський бізнес зазнав значного впливу з боку розвитку цифрових та інфрормаційних технологій. Банківництво в реаліях сучасного цифрового суспільства - бізнес побудований на: цілодобових послугах; нових можливостях та інноваціях; здатності швидко реагувати на зміни та потреби суспільства; використанні мобільних додатків, чат-ботів, банкоматів, POSтерміналів для надання послуг.

Важливе місце в розвитку срінансового посередництва та наданні фрінансових послуг займає впровадження та розвиток альтернативних видів платежів. Такі рішення пропонуються для розширення безготівкових платежів та альтернативних каналів трансакцій (мобільні мережі, криптовалюти, Р2Р-платсрорми, M2M-payments, хмарні платежі тощо).

Особливу увагу слід приділити цифровій альтернативі готівковим коштам - віртуальним активам, зокрема, криптовалютам та блокчейн-технологіям, на яких вони ґрунтуються. Інтерес до віртуальних активів та блокчейн технологій, спричинений зростаючою популярністю криптовалют, передусім, біткойна. Ця популярність не пройшла повз увагу законодавчих органів України. Так, вже зараз обговорюються уточнення й доповнення до законопроекту № 3637 «Про віртуальні активи», в якому передбачено комплексне врегулювання правовідносин, що виникають у зв'язку з обігом віртуальних активів в Україні, визначено права та обов'язки учасників цього ринку, засади державної політики у сорері обігу віртуальних активів [1; 2].

Відбувається зростання інтересу наукової спільноти до мотивів застосування віртуальних активів і технологій, на яких вони ґрунтуються, в контексті економіки, менеджменту та фрінансів. Однією з таких технологій $є$ блокчейн. Думки авторитетних джерел щодо цієї технології різняться. За деякими песимістичними прогнозами ця технологія спричинить виникнення значних перешкод для таких фрінансових посередників, як банки. Однак інші науковці вважають, що блокчейн-технології здатні посприяти переходу фрінансових відносин на вищий рівень [3, с. 19; 4]. 
Вже зараз здійснюються розробка та впровадження проектів, пов'язаних 3 блокчейнтехнологіями у банківській сорері. Серед особливо значимих прикладів виділимо [5, с. 2-5]:

1. JP Morgan Chase, який створив підрозділ Quorum для вивчення додатків на основі блокчейну, таких як річний сертифрікат депозитів зі змінними ставками за допомогою смарт-контрактів для забезпечення швидких трансакцій.

2. Bank of America подав патент на дозволену мережу блокчейн для ведення безпечних записів, аутентифрікації особистих та ділових даних. Допущені користувачі зможуть отримувати доступ до даних і вести облік усіх записів, а існуючі застарілі системи зберігання будуть об'єднані в одну книгу на основі блокчейну.

3. BNP Paribas вивчає використання рішень на основі блокчейну для обробки замовлень та валютних коштів.

4. Fujitsu співпрацює з Японською асоціацією банкірів (JBA) для тестування цифррових валют і програм міжбанківських розрахунків на основі блокчейну.

Блокчейн можна розглядати як розподілену публічну книгу, де групи трансакцій або подій записуються та зберігаються у послідовній, ланцюгоподібній структурі даних. Такі групи трансакцій називаються блоками і впорядковуються в ланцюжку за часом проведення трансакцій. Далі блоки, кількість яких є необмеженою, додаються до кінця ланцюга, зберігаючи хеш попереднього блоку. Змістовно блок може містити будь-яку інфрормацію: про дії, людей, об'єкти, трансакції, серійні номери, видані кредити тощо. В цій системі кожен учасник має ідентичну копію книги обліку. Якщо будь-який конкретний вузол у системі несправний, інформація не буде втрачена безповоротно, а буде збережена в повному обсязі та повноті, оскільки кожен інший учасник має копію точно такої ж бази даних. Крім того, зберігається журнал трансакцій, а не тільки кінцеві результати (наприклад, дані про поточні залишки), що захищає систему від маніпуляцій або фральсифрікації даних. Цифрровий підпис учасників угоди засвідчує дійсність угод. Підписані трансакції сортуються в окремі блоки, і кожному блоку в цьому ланцюжку присвоюється унікальний, так званий «хеш-код», який генерується комп'ютерами за допомогою складної математичної фрормули. Внесення змін до даних про трансакції змінить хеш-код блоку, де вони зберігаються. Важливо, що ці зміни відображаються одно- часно в усіх блоках ланцюга. Таким чином, можлива зміна буде, по-перше, негайно зареєстрована, а по-друге - негайно ідентифрікована та відстежена всіма учасниками мережі. Завдяки цьому блокчейн має низку переваг, включаючи автентисрікацію однорангових трансакцій та автоматизований, зашиорований реєстр таких трансакцій, що фрункціонує в режимі у реального часу $[6$, с. 20,$21 ; 7$, с. 20 ; 8, c. 366; 9].

Поряд із позитивними характеристиками блокчейну, існують певні недоліки цієї технології. Масове застосування блокчейн-технологій стикається 3 невирішеними проблемами технологічного, правового, нормативного й етичного характеру. Проблеми технологічного характеру зумовлені специфрікою фрункціонування блокчейну. Шисррування записів може зробити неможливим доступ до системи у разі втрати пароля. Висока енергоємність так званого майнінгу, що забезпечує необхідну децентралізацію екосистеми блокчейн, залишається невирішеною. Все ще актуальна проблема відсутності механізму скасування помилкових операцій. Зміст юридичних проблем можна узагальнити таким чином: хоча записи в розподілених книгах, побудованих на основі технологій блокчейну, є достовірними та незмінними, проте досі не існує детального правового регулювання трансакцій, здійснених на платорормі блокчейну. Наприклад, якщо між двома сторонами є спір або судові процеси, незрозуміло, як це вплине на статус їхніх угод. Необхідна законодавча база також дасть змогу регулюючим органам ефективніше виконувати свою наглядову фрункцію. Недовіра з боку регуляторів до блокчейн-технологій також пов'язана з незрілістю й експериментальним характером цих технологій.

3 огляду на це, пропонуємо узагальнення та систематизацію характеристик блокчейну 3 позиції безпеки банків (рис. 1). До переваг блокчейн-технолій у банківській справі віднесемо: надійність, компроміс та безпечність. Серед недоліків виділяємо: енергозалежність, енергозатратність, виникнення нових кібервразливостей та ускладнення фрінансового моніторингу. Характеристики блокчейнтехнологій, які не можуть бути однозначно віднесені до переваг чи недоліків такі: коноріденційність, прозорість, децентралізація, відсутність стандартів, новизна для клієнта.

Серед головних мотивів застосування блокчейну в банківській справі виділимо: мотив ефективності, мотив безпеки, мотив автономії та мотив контролю. Мотив автономії 


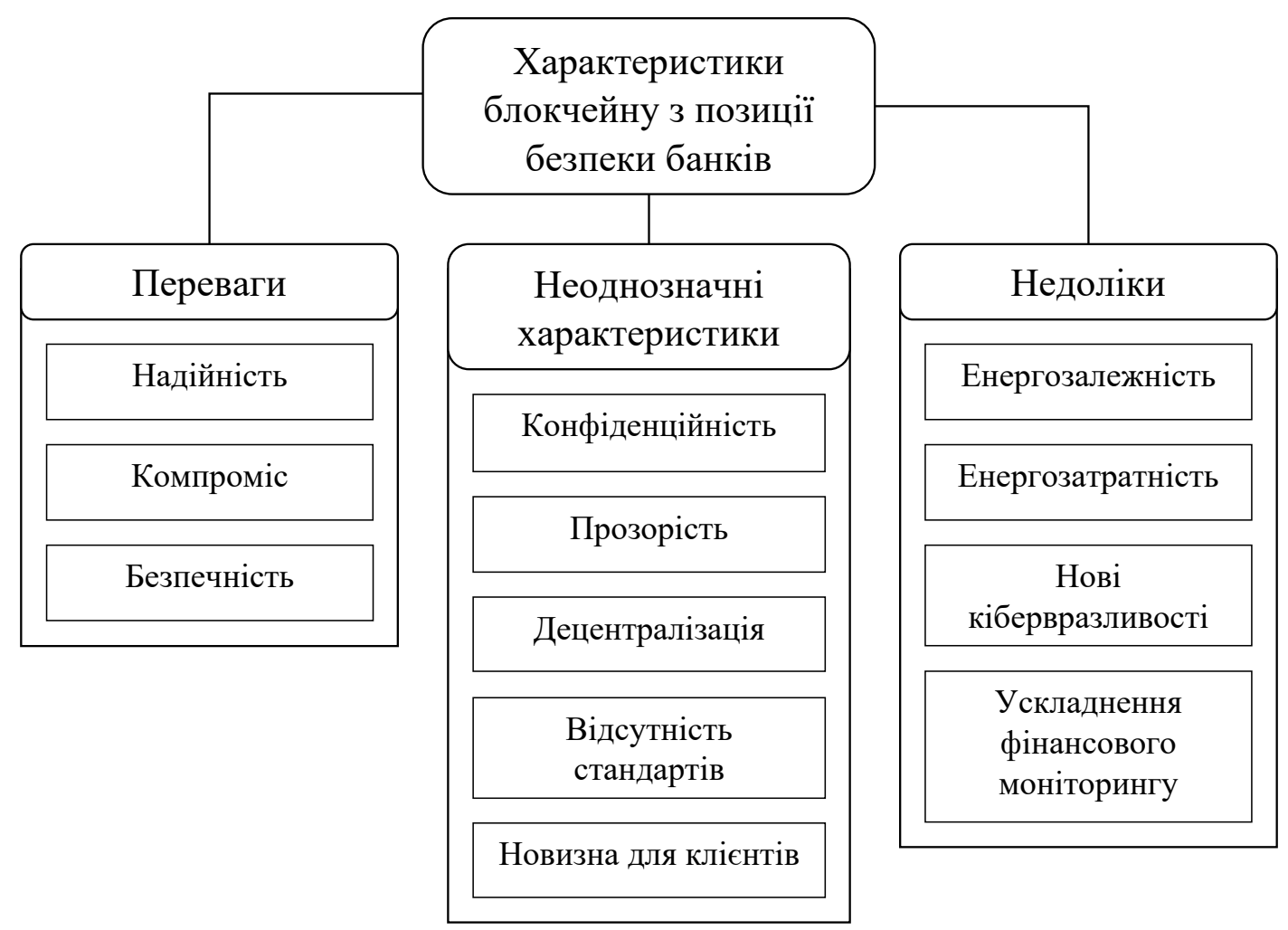

Рис. 1. Характеристики блокчейну з позиції безпеки банків Джерело: складено авторами на основі [10; 11]

пов'язаний із бажанням індивіда мати певну свободу, тоді як мотив контролю стосується бажання мати інформацію про інших та впливати на їхню поведінку. Мотиви та відповідні характеристики блокчейну, що відповідають або не відповідають кожному з них систематизовані в таблиці 1.
Перший мотив реалізується тим, що блокчейн забезпечує надійність при здійсненні операцій. Проте цьому мотиву не сприяє енергозатратність даної технології, відсутність єдиних стандартів, необізнаність клієнтів, ускладнення фрінансового моніторингу.

Характеристики блокчейну та їх відповідність мотивам його застосування у банківській справі

\begin{tabular}{|c|c|c|}
\hline Мотив & $\begin{array}{c}\text { Характеристики, } \\
\text { що відповідають мотиву }\end{array}$ & $\begin{array}{c}\text { Характеристики, } \\
\text { що не відповідають мотиву }\end{array}$ \\
\hline Ефрективності & Надійність & $\begin{array}{c}\text { Енергозатратність; } \\
\text { Відсутність стандартів; } \\
\text { Новизна для клієнта; } \\
\text { Ускладнення фрінансового моніторингу }\end{array}$ \\
\hline Безпеки & $\begin{array}{l}\text { Надійність; } \\
\text { Безпечність; } \\
\text { Прозорість }\end{array}$ & $\begin{array}{c}\text { Енергозалежність; } \\
\text { Відсутність стандартів; } \\
\text { Нові кібервразливості; } \\
\text { Ускладнення фрінансового моніторингу }\end{array}$ \\
\hline Автономії & $\begin{array}{c}\text { Коноріденційність; } \\
\text { Децентралізація; } \\
\text { Відсутність стандартів }\end{array}$ & $\begin{array}{c}\text { Енергозалежність; } \\
\text { Прозорість }\end{array}$ \\
\hline Контролю & $\begin{array}{l}\text { Прозорість; } \\
\text { Компроміс }\end{array}$ & $\begin{array}{c}\text { Енергозалежність; } \\
\text { Децентралізація; } \\
\text { Нові кібервразливості; } \\
\text { Ускладнення фрінансового моніторингу }\end{array}$ \\
\hline
\end{tabular}


Другий мотив пов'язаний зі зростанням надійності, безпеки та захисту від збоїв інформаційної системи, унеможливленням несанкціонованого доступу до системи шляхом використання цифррового підпису і шифррування. Разом з тим, даному мотиву не відповідають такі характеристики як: енергозалежність технології, відсутність єдиних стандартів, нові кібервразливості, ускладнення фрінансового моніторингу.

Третій мотив забезпечується зростанням консріденційності користувачів блокчейну, підвищенням децентралізації та відсутності єдиних стандартів. На противагу цим характеристикам виступають: енергозалежність та прозорість технології.

Четвертий мотив узгоджується із прозорістю та компромісністю блокчейн-технологій. Характеристики, що проявляються всупереч цьому мотиву: енергозалежність, децентралізація, нові кібервразливості, ускладнення фрінансового моніторингу [3, с. 28 ; 8 , с. 380 ; 12, с. $19-21 ; 13]$.

Висновки. Застосування блокчейну у банківській справі може ґрунтуватись на таких головних мотивах: ефрективності, безпеки, автономії та контролю. Окремі характеристики блокчейну різною мірою узгоджуються 3 відповідними мотивами або перешкоджають їх реалізації. Тому фрінансові мотиви використання блокчейну в банківській справі пов'язані
3 низкою переваг, недоліків та неоднозначних характеристик відповідної технології. Це може поставити під сумнів переваги співпраці та рентабельність інвестицій у блокчейн-проекти. Разом 3 тим, $є$ підстави прогнозувати, що запровадження блокчейну, швидше за все, матиме загальносистемний характер, як тільки буде вирішено проблеми нормативного й технологічного забезпечення.

Надійність застосування технології блокчейн у сучасних умовах визначається не стільки правовими та етичними чинниками, скільки особливостями тих чи інших прийомів криптографої. Однак криптограсрічні засоби наразі недостатньо адаптовані до низки практичних проблем, наприклад, застосування механізму скасування помилкових операцій. Намагання значної частини прихильників криптовалют уникнути будь-яких регуляторних впливів зумовлює відсутність загальноприйнятих стандартів застосування блокчейну. Тому варто очікувати розвитку цієї сорери у конкурентному еволюційному фрорматі, що буде супроводжуватись значними кризовими явищами на шляху відбору життєздатних технологій. Успішність застосування блокчейн технології окремими банками залежить від здатності обирати дієві технологічні рішення та здійснювати управління ризиками ділових відносин у сорері обігу віртуальних активів.

\section{СПИСОК ВИКОРИСТАНИХ ДЖЕРЕЛ:}

1. Законопроект «Про віртуальні активи». URL: http://w1.c1.rada.gov.ua/pls/zweb2/webproc4_1?pf3511=69110

2. Офіційний сайт Верховної Ради України. URL: https://www.rada.gov.ua/news/Novyny/213503.html

3. Dancho Petrov. Blockchain Ecosystem in the Financial Services Industry. FAIMA Business \& Management Journal. 2020. Volume 8. Issue 1. P. 19-29. URL: http://www.faimajournal.ro/full_issue/26.\%20INTERIOR\%20 Revista\%20FAIMA\%20Vol\%208\%20-\%20Issue\%201\%20[March\%202020].pdf\#page=19

4. Rebecca Lewis, John McPartland, Rajeev Ranjan. Blockchain and financial market innovation. J.P. Morgan Center For Commodities. UNIVERSITY OF COLORADO DENVER BUSINESS SCHOOL. 2019. URL: http://www.jpmcc-gcard.com/wp-content/uploads/2019/03/GCARD-Summer-2019-Chicago-Fed.pdf

5. Dulani Jayasuriya Daluwathumullagamage, Alexandra Sims. Fantastic Beasts: Blockchain Based Banking. Journal of Risks and Financial Management. URL: http://www.mdpi.com/1911-8074/14/4/170

6. Derrick Bonyuet. Overview and Impact of Blockchain on Auditing. The International Journal of Digital Accounting Research. 2020. Vol. 20. P. 31-43. DOI: https://doi.org/10.4192/1577-8517-v20_2

7. Manlu Liu, Kean Wu, Jennifer Jie Xu. How Will Blockchain Technology Impact Auditing and Accounting: Permissionless versus Permissioned Blockchain. American Account Association. 2019. Vol. 13. Number 2. P. 19-29. DOI: https://doi.org/10.2308/ciia-52540

8. Marion Pauline Gauthier, Nathalie Brender. How do the current auditing standards fit the emergent use of blockchain? Managerial Auditing Journal. 2021. Vol. 36 No. 3. 365-385. DOI: https://doi.org/10.1108/MAJ-12-2019-2513

9. Thomson Reuters. KYC Challenges in 2017: A Focus on the Impact of Global Regulations in the United States. URL: https://risk.thomsonreuters.com/..kyc-challenges-2017-usa.pdf

10. Що таке Блокчейн (Blockchain)? Технологія розподіленого реєстру простими словами. URL: http://bitcoin-crypto-portal.com/scho-take-blokcheyn-blockchain-tehnolog-ya-rozpod-lenogo-re-stru-prostimi-slovami/

11. The BlueNoroff cryptocurrtncy hunt is still on. URL: https://securelist.com/the-bluenoroff-cryptocurrencyhunt-is-still-on/105488 
12. Najoua Elommal, Riadh Manita. How blockchain innovation could affect the audit proffesion: a qualitative study. «Journal of Innovation Economics \& Management». Prepublication.103. 2021. DOI: https://doi.org/10.3917/ jie.pr1.0103

13. Higginson, M., Nadeau, M., Rajgopal, K. Blockchain's Occam Problem. McKinsey on Payment. 2019. URL: https://www.mckinsey.com/industries/financialservices/our-insights/blockchains-occam-problem

\section{REFERENCES:}

1. The bill "On virtual assets". Retrived from: http://w1.c1.rada.gov.ua/pls/zweb2/webproc4_1?pf3511=69110

2. Official site of the Verkhovna Rada of Ukraine. Retrived from: https://www.rada.gov.ua/news/Novyny/213503.html

3. Dancho Petrov (2020) Blockchain Ecosystem in the Financial Services Industry. FAIMA Business \& Management Journal, vol. 8, iss. 1, pp. 19-29. Retrived from: http://www.faimajournal.ro/full_issue/26.\%20INTERIOR\%20 Revista\%20FAIMA\%20Vol\%208\%20-\%20Issue\%201\%20[March\%202020].pdf\#page=19

4. Rebecca Lewis, John McPartland, Rajeev Ranjan (2019) Blockchain and financial market innovation. J.P. Morgan Center For Commodities. UNIVERSITY OF COLORADO DENVER BUSINESS SCHOOL. Retrived from: http://www.jpmcc-gcard.com/wp-content/uploads/2019/03/GCARD-Summer-2019-Chicago-Fed.pdf

5. Dulani Jayasuriya Daluwathumullagamage, Alexandra Sims. Fantastic Beasts: Blockchain Based Banking. Journal of Risks and Financial Management. Retrived from: http://www.mdpi.com/1911-8074/14/4/170

6. Derrick Bonyuet (2020) Overview and Impact of Blockchain on Auditing. The International Journal of Digital Accounting Research, vol. 20, pp. 31-43. DOI: https://doi.org/10.4192/1577-8517-v20_2

7. Manlu Liu, Kean Wu, Jennifer Jie Xu (2019) How Will Blockchain Technology Impact Auditing and Accounting: Permissionless versus Permissioned Blockchain. American Account Association, vol. 13, no. 2, pp. 19-29. DOI: https://doi.org/10.2308/ciia-52540

8. Marion Pauline Gauthier, Nathalie Brender (2021) How do the current auditing standards fit the emergent use of blockchain? Managerial Auditing Journal, vol. 36, no. 3, pp. 365-385. DOI: https://doi.org/10.1108/MAJ-12-2019-2513

9. Thomson Reuters. KYC Challenges in 2017: A Focus on the Impact of Global Regulations in the United States. Retrived from: https://risk.thomsonreuters.com/..kyc-challenges-2017-usa.pdf

10. What is Blockchain? Distributed registry technology in simple words. Retrived from: http://bitcoin-cryptoportal.com/scho-take-blokcheyn-blockchain-tehnolog-ya-rozpod-lenogo-re-stru-prostimi-slovami/

11. The BlueNoroff cryptocurrtncy hunt is still on. Retrived from: https://securelist.com/the-bluenoroff-cryptocurrency-hunt-is-still-on/105488

12. Najoua Elommal, Riadh Manita (2021) How blockchain innovation could affect the audit proffesion: a qualitative study. «Journal of Innovation Economics \& Management». Prepublication.103. DOI: https://doi.org/10.3917/ jie.pr1.0103

13. Higginson, M., Nadeau, M., Rajgopal, K. (2019) Blockchain's Occam Problem. McKinsey on Payment. Retrived from: https://www.mckinsey.com/industries/financialservices/our-insights/blockchains-occam-problem 